\title{
Impact of the aqueous extract of dandelion, probiotic and their synbiotic on male lamb's testicular histopathology relative to semen characteristics
}

\author{
Moustafa Zeitoun ${ }^{1 *}$, Mohamed Farahna ${ }^{2}$, Khaled Al-Sobayil $^{1}$, Ahmed Abdel-Salam ${ }^{3}$

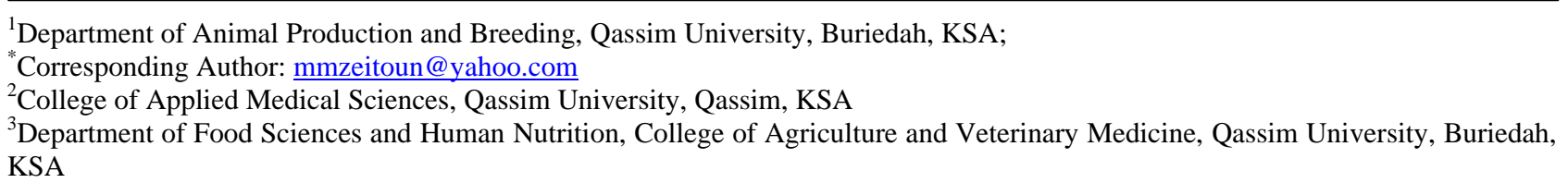

Received 23 December 2013; revised 8 January 2014; accepted 16 January 2014

Copyright (C) 2014 Moustafa Zeitoun et al. This is an open access article distributed under the Creative Commons Attribution License, which permits unrestricted use, distribution, and reproduction in any medium, provided the original work is properly cited. In accordance of the Creative Commons Attribution License all Copyrights (C) 2014 are reserved for SCIRP and the owner of the intellectual property Moustafa Zeitoun et al. All Copyright (C) 2014 are guarded by law and by SCIRP as a guardian.

\section{ABSTRACT}

This study aimed at investigating effects of dandelion/probiotic on the testis histology and semen characteristics of male lambs. Twelve prepuberal Noemi male lambs $(2 \pm 0.4$-month-old and $20 \pm 3.5 \mathrm{~kg} \mathrm{B.W}$ ) were randomly allocated into four groups. Animals in group 1 were controlled, orally given normal saline as the same schedule of treated animals. In group 2 animals were given daily oral $50 \mathrm{ml}$ of an aqueous extract of dandelion leaves. In group 3 animals were given a daily $50 \mathrm{ml}$ of cow's milk probiotics, and in group 4 animals were given $50 \mathrm{ml}$ of a 1:1 mixture (dandelion extract: probiotic). Animals were treated for 8 consecutive weeks. At puberty, semen ejaculates were collected weekly for further 10 weeks. Thereafter, animals were sacrificed and testicles were obtained, weighed and a histopathological study was performed on the testis. Results revealed that oral administration of the dandelion aqueous extract to prepuberal lambs exhibited disturbances in the histological architecture of the testicular semeniferous tubules. Additionally, dandelion resulted in edematic interstitial tissues with evident vaculations. These deteriorations were reflected in less spermatogenesis (i.e. less sperm concentration and ejaculate volume by $10 \%$ and $20 \%$, respectively than controlled group). Also, the percentage of sperm progressive motility was lower $(\mathrm{P}<$ $0.05)$ and dead sperm was higher $(P<0.05)$ in rams given dandelion than control. Administration of probiotic hasn't revealed a change in the seminiferous tubules architecture, however, very little vaculation with rare edema was observed. Administration of the synbiotic mixture revealed intermediate histopathological appearances. The highest sperm concentration, testosterone concentration and advanced motility were obtained when probiotic was administered. In conclusion, although dandelion cures some hepatic malfunctions in human, caution must be taken into consideration of the frequent ingestion of dandelion for its harmful effect on male fertility.

\section{KEYWORDS}

Dandelion; Histopathology; Probiotic; Ram; Semen; Testis

\section{INTRODUCTION}

Dandelion (Taraxacum officinale) leaves and roots have been used for hundreds of years to treat liver, gallbladder, kidney, and joint problems. Dandelion is traditionally considered as an alternative and is used for conditions as varied as eczema and cancer [1]. In North America, the Iroquois people prepared infusions and decoctions of the root and whole herb to treat kidney disease, dropsy, and dermatological conditions. As is the case today, dandelion leaves have also been used historically as a diuretic.

In traditional Chinese medicine, it is also acclaimed as 
a nontoxic herb with exceptional values for its choleretic, diuretic, anti-rheumatic and anti-inflammatory properties. Several flavonoids including caffeic acid, chlorogenic acid, luteolin, and luteolin 7-glucoside have been isolated from the dandelion [2]. Dandelion fresh leaves contain protein, fiber, calcium, phosphorus, iron, potassium, thiamine, riboflavin, vitamin $\mathrm{C}$, and are especially high in vitamin $\mathrm{A}$. The dried leaf is high in potassium (about 4\%). Dandelion was included as a diuretic in the US pharmacopeia from 1831 to 1926 [3]. Based on its diuretic effects, dandelion is often included in herbal weight loss and premenstrual syndrome remedies. Some herbalists also recommend dandelion as an herb useful to help prevent atherosclerosis [4]. Others suggest that it may be a useful spring and fall tonic for patients with chronic osteoarthritis and those with a tendency to form gallstones [5]. In addition to its medicinal uses, dandelion serves as a green salad in the gourmet's garden and as an unwelcome weed in the well-manicured lawn. The leaves are an excellent source of vitamin A. The ground roots are sometimes used as a substitute for chicory roots or coffee beans. The flowers are sometimes fermented into wine. The root is the part most often medicinally used [6]. The German Commission E approves it for use as a diuretic and to treat dyspepsia, liver and gallbladder complaints and appetite loss $[7,8]$. Recent data on rats revealed that dandelion may have a serious side effect on male fertility. According to an earlier fertility study conducted on mice, plant materials derived from Taraxacum mongolicum and other compositae family pose no risk to fertility [9]. Fertility data specific to Taraxacum officinale are not available. However, recently an aqueous extract of dandelion acts as an anti-fertility agent, as it decreases male rat fertility in vivo. Experimental groups received an orally aqueous extract of dandelion for 60 days in two different sub lethal doses; $1 / 10 \mathrm{LD}_{50}$ as high dose and $1 / 20 \mathrm{LD}_{50}$ as low dose, whereas the control group received distilled water. The administration of the aqueous extract of Taraxacum officinale resulted in a significant decrease in testis weight in the two experimental groups. Also, distortion of morphology of the seminiferous tubules and arrest in spermatogenesis were observed in the experimental groups [10]. Due to the controversy in this issue, the current study was designed to investigate the effect of administering an aqueous extract of dandelion leaves without/or with cow's fermented milk probiotic, on the histopathological appearance of ram testes in relation to semen characteristics. The inclusion of probiotic was targeted to ameliorate the adverse consequences on testicular function.

\section{MATERIAL AND METHODS}

\subsection{Animals and Treatments}

Twenty four prepuberal Noeimi male lambs aging $2 \pm$
0.2 months and weighing $20 \pm 3.5 \mathrm{~kg}$ were raised in the experimental station of Qassim University, central of Saudi Arabia. Animals were offered pelleted ration in addition to green fodder (Trifolium alexandrinum) according to the requirement of the AOAC [11] and have accessibility to clean tap water. Animals were randomly allocated into four treatment groups ( $n=6$ /group). Group 1 animals served as control and orally given $50 \mathrm{ml}$ saline $(0.9 \% \mathrm{NaCl})$ every other day throughout the experimentation period (8 weeks), group 2 animals were given 50 $\mathrm{ml}$ of an aqueous extract of dandelion (6\%) as the same schedule in the control, group 3 animals were given 50 $\mathrm{ml}$ fermented cow milk probiotic in the same manner and group 4 animals were given $50 \mathrm{ml}$ of the mixture (dandelion: probiotic; $1: 1$ ) in the same schedule. Animals were observed for health status and attainment of puberty signs (i.e. the first mount with complete erection).

\subsection{Semen Collection and Evaluation}

At puberty semen was collected via an artificial vagina and estrous ewe. Ejaculates were collected once a week for ten consecutive weeks. Gross and physical evaluations were done on each ejaculate (i.e. ejaculate volume, sperm concentration, gross motility, individual progressive motility, percent dead sperm, semen $\mathrm{pH}$ ).

\subsection{Blood Collection and Serum Harvesting}

Concomitant to the semen collection a venipuncture Jugular blood sample was collected in heparin-free Vacutainer ${ }^{\circledR}$ tube of three animals within a treatment (i.e. total 12 animals) once per week throughout 10 consecutive weeks for the determination of testosterone. Blood samples were cooled for two hours prior to the centrifugation (3000 rpm $/ 30 \mathrm{~min} / 5^{\circ} \mathrm{C}$ ). Serum was harvested and kept frozen $\left(-20^{\circ} \mathrm{C}\right)$ until further used for testosterone determinations.

\subsection{Testosterone Determinations}

Testosterone was determined according to Moltz et al. [12] by a commercial ELISA kit (HUMAN Diagnostic Co., Germany). Testosterone determinations sensitivity range was $0.05-0.09 \mathrm{ng} / \mathrm{ml}$ and intra- and inter-assay coefficient of variations were $2.9 \%$ and $4.7 \%$, respectively.

\subsection{Proximate Analysis of Dandelion Dry Leaves}

The chemical composition of dandelion was performed in the biochemistry laboratory and the mean data of analyzing 10 samples of various locations of the crushed powder of dandelion leaves are shown in Table 1.

\subsection{Milk and Bacterial Culture}

Milk samples were obtained from healthy lactating 
Table 1. Chemical composition of dandelion leaves $(\mathrm{M} \pm$ SEM).

\begin{tabular}{cc}
\hline Nutrient & Value (\%, based on Dry Matter) $^{*}$ \\
\hline Protein & $56.78 \pm 3.27$ \\
Ether Extract & $14.22 \pm 1.19$ \\
Carbohydrate & $21.55 \pm 1.96$ \\
Ash & $7.45 \pm 0.67$ \\
\hline
\end{tabular}

*Mean of 10 samples.

animals located at the experrimental station of the University of Qassim (Al-Qasiim region-Saudi Arabia). Starter cultures of Streptococcus thermophilus, Lactobacillus acidophilus and Bifidobacterium bifidum were obtained from Chr. Hansen's Laboratory, Copenhagen Denemark.

\subsection{Preparation of Probiotic Fermented Milk}

Preparation of probiotic fermented milk was carried out according the methods of traditional fermented manufacturing, which carried out using the methods described by [13]. Fresh cow milk have been standardized to achieve about $12 \%$ total solid content, and then heated at $85^{\circ} \mathrm{C}$ for $15 \mathrm{~min}$, cooled to $40^{\circ} \mathrm{C}$, inoculated with probiotic bacteria (2\%) and then incubated for $4-8 \mathrm{~h}$ at $42^{\circ} \mathrm{C}$. After coagulation, the curd has been tested for $p \mathrm{H}$, then stirred in an electric blender and stored refrigerated $\left(5^{\circ} \mathrm{C}\right)$. The fresh milk was analyzed according to AOAC method [14]. The analysis data of milk were as follow; 2.90 fat, $8.66 \%$ solids not fat, $3.24 \%$ protein, $4.73 \%$ lactose, $0.65 \%$ ash, $1.0261 \mathrm{~kg} / \mathrm{m}^{3}$ density and $-0.408^{\circ} \mathrm{C}$ freezing point.

\subsection{Preparation of Aqueous Extracts of Dandelion (Taraxacum officinalis)}

Dried dandelion (Taraxacum officinalis) leaves and roots weres purchased from local market. Aqueous extract of dandelion (Taraxacum officinalis) containing prebiotic ingredients (prebiotic extract) has been carried out using a method described by Melendeza and Caprilesa [15]. The plant material was pulverized in a grinder. Sixty grams of the pulverized material have been dissolved and extracted with $1000 \mathrm{ml}$ hot distilled water in an electric blender which left running for $15 \mathrm{~min}$. Afterwards, the suspension was left at room temperature for 1 hour, then filtered twice, first through cheese-cloth (50\% cotton/50\% polyester) and then through filter paper (Whatman No.2). The clear aqueous extract was preserved in sterile dark bottles $(500 \mathrm{ml})$ at $-20^{\circ} \mathrm{C}$ until further use.

\subsection{Preparation of Synbiotic}

Synbiotic syrup was prepared by combining equal volumes (v:v) of protective fermented milk with aqueous extract of dandelion (Taraxacum officinalis).

\subsection{Statistical Analysis}

Data for semen parameters were analyzed by the least square analysis of variances [16]. Differences of means among treatments were compared by the Duncan's Multiple Range Test (DMRT) [17]. Significance level was considered at $\mathrm{P}<0.05$.

\subsection{Histopathological Examination}

Samples of testis were taken, and fixed in $10 \%$ neutral buffered formalin for 24 hours. Paraffin sections $6 \mu \mathrm{m}$ thick were prepared and stained with hematoxylin and eosin ( $\mathrm{H} \& \mathrm{E}$ ) for the examination of tissue and cellular changes by light microscopy $[18,19]$.

\section{RESULTS}

\subsection{Semen Characteristics}

Throughout the entire study we mean by the term "Prebiotic" dandelion leaves aqueous extract.

Semen ejaculate volume (Figure 1) decreased significantly $(\mathrm{P}<0.01)$ in rams given prebiotic $(0.92 \mathrm{ml})$ as compared to control $(1.18 \mathrm{ml})$ rams. Percent of reduction in ejaculate volume was about $22 \%$. However, there were no obvious differences in ejaculate volume among other treatments (1.14 and $1.12 \mathrm{ml}$ for symbiotic and probiotic, respectively).

Sperm concentration (Figure 2) was highest in rams given fermented milk probiotic $\left(3.65 \times 10^{9} \mathrm{sperm} / \mathrm{ml}\right)$ than control and other treatments. Taraxacum officinale aqueous solution slightly $(\mathrm{P}>0.05)$ decreased the sperm count $\left(2.57 \times 10^{9}\right.$ sperm/ml) by about $28 \%$ of the control value $\left(2.8 \times 10^{9}\right.$ sperm $\left./ \mathrm{ml}\right)$.Combining the fermented milk with the dandelion extract (i.e. synbiotic) ameliorated this effect $\left(2.76 \times 10^{9}\right.$ sperm $\left./ \mathrm{ml}\right)$.

Sperm individual progressive motility (Figure 3 ) was reduced $(\mathrm{P}<0.001)$ in rams administered Taraxacum officinale (47.2\%) as compared to control (54.2\%), this represent about $15 \%$ decrease. On the other hand, probiotic significantly $(\mathrm{P}<0.001)$ increased sperm motility than control and other treatments $(63.0 \%$ and $50.3 \%$ for probiotic and synbiotic rams, respectively). The increase that has been gained by drinking the fermented milk on sperm motility reached $16 \%$ above the control rams. Combining fermented milk with the dandelion did not enhance its effect on sperm motility.

Furthermore, prebiotic (22.4\%) and synbiotic (26.4\%) increased $(\mathrm{P}<0.001)$ percentage of dead sperm (Figure 4) as compared to control (17.1\%), however rams given probiotic gave ejaculates with the lowest percent of dead sperm $(14.7 \%)$. The difference due to probiotic treatment on percent dead sperm was not statistically significant. 


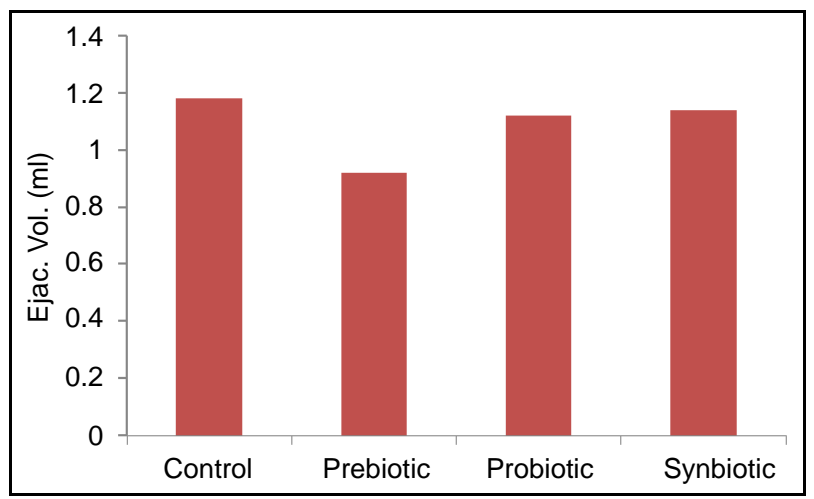

Figure 1. Effects of prebiotic, probiotic and synbiotic on ram ejaculate volume.

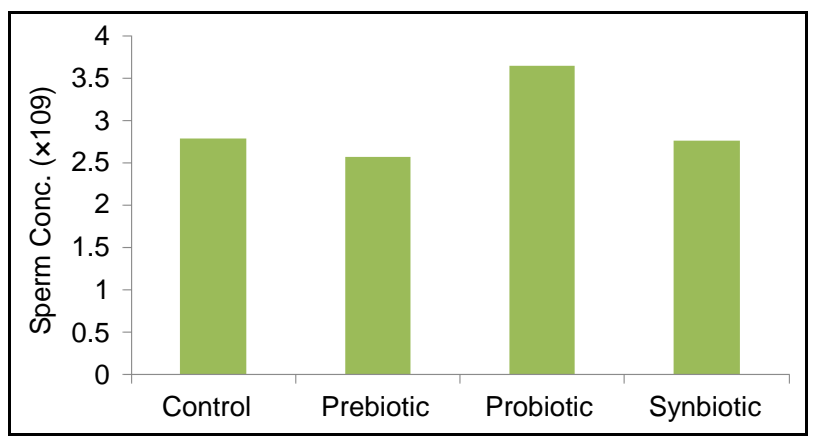

Figure 2. Effects of prebiotic, probiotic and synbiotic on the ram sperm concentration.

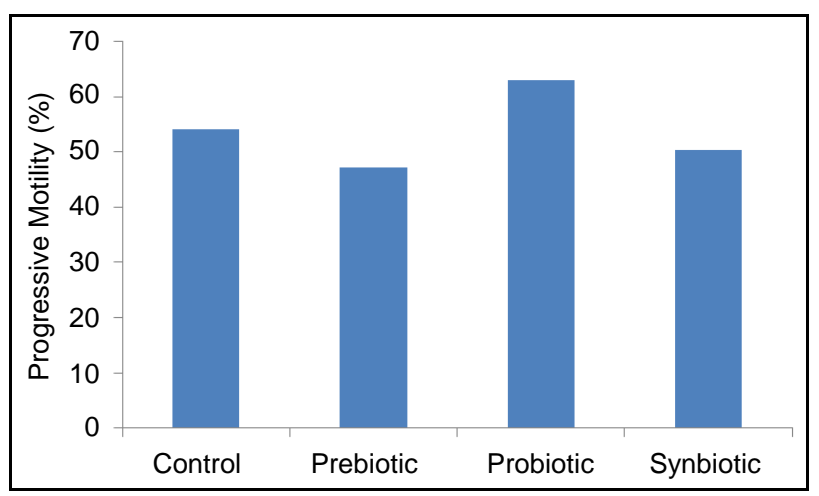

Figure 3. Effects of prebiotic, probiotic and synbiotic on the percentage of ram progressive motile sperm.

Semen $p \mathrm{H}$ value (Figure 5) was not statistically ( $\mathrm{P}>$ 0.05 ) different among treatments, even though administration of Taraxacum officinale decreased the $p \mathrm{H}$ value to be more acidic (6.14), however $p \mathrm{H}$ value of the control semen was 6.86 , close to neutral.

Percent of abnormal sperm (Figure 6) was not different $(\mathrm{P}>0.05)$ among treatments (range, 6.6\% - 7.1\%).

\subsection{Blood Testosterone}

There found significant differences $(\mathrm{P}<0.01)$ among treatments on serum testosterone (5.36, 4.33, 6.31 and

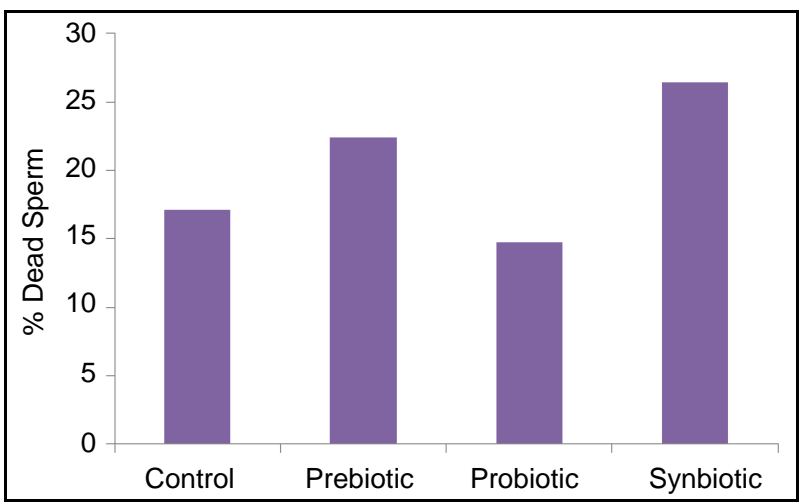

Figure 4. Effects of prebiotic, probiotic and synbiotic on the ram percentage of dead sperm.

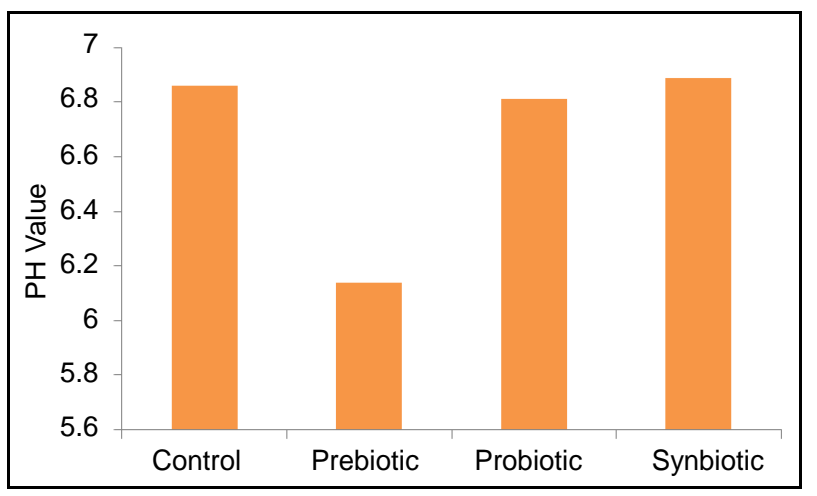

Figure 5. Effects of prebiotic, probiotic and synbiotic on the ram semen $p \mathrm{H}$ value.

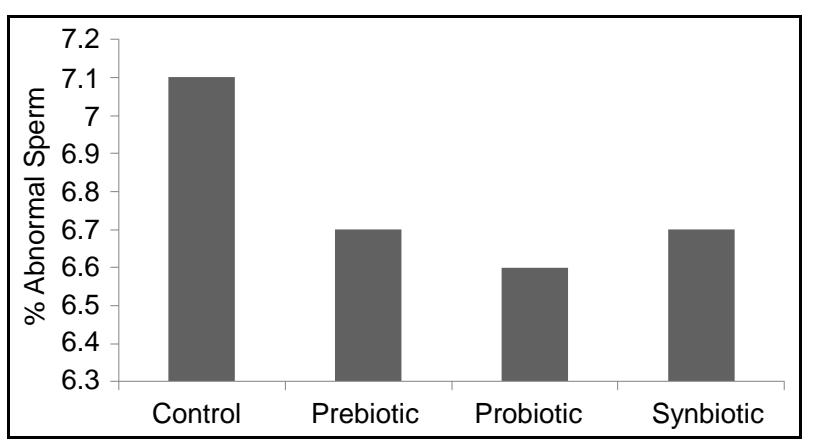

Figure 6. Effects of prebiotic, probiotic and synbiotic on percentage of abnormal sperm of ram semen.

$5.73 \mathrm{ng} / \mathrm{ml}$, for control, pre-, pro- and synbiotic, respectively). Dandelion extract significantly decreased peripheral testosterone concentration by about $19 \%$ than in control; however probiotic increased testosterone by about $18 \%$. Even though, synbiotic showed a slight elevation in testosterone, but not significant (Figure 7).

\subsection{Histopathology of Testes}

Histopathological changes in the testis sections stained with H\&E were evaluated by light microscopy. A summary of the evaluations is shown in Table 2. There found 


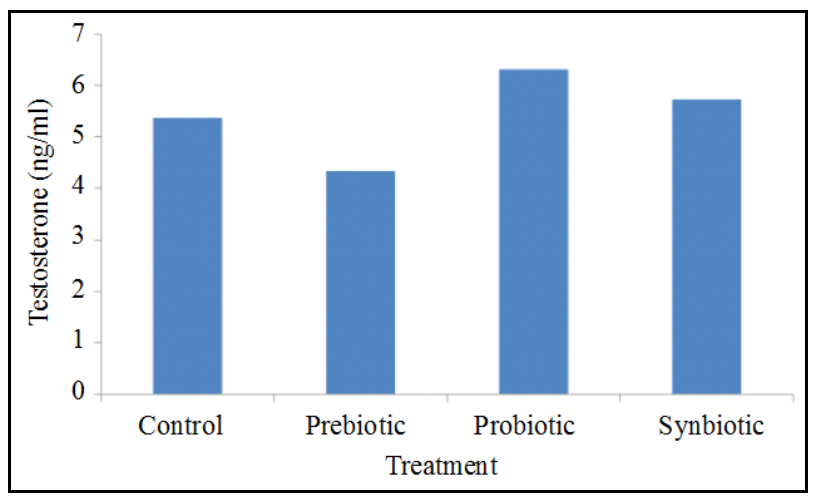

Figure 7. Effects of prebiotic, probiotic and synbiotic on peripheral testosterone of rams.

Table 2. Histopathological changes in lamb’s testes as influenced by dandelion, probiotic and their synbiotic mixture.

\begin{tabular}{|c|c|c|c|c|}
\hline $\begin{array}{c}\text { Tissue and cellular } \\
\text { changes }\end{array}$ & Control & $\begin{array}{c}\text { Dandelion } \\
\text { extract }\end{array}$ & Probiotic & Synbiotic \\
\hline Interstitial tissue Edema & - & ++ & + & ++ \\
\hline $\begin{array}{l}\text { Interstitial tissue } \\
\text { Vaculation }\end{array}$ & - & ++ & + & ++ \\
\hline $\begin{array}{l}\text { Histo-architecture } \\
\text { disturbance of } \\
\text { seminiferous Tubules }\end{array}$ & - & ++ & + & + \\
\hline $\begin{array}{l}\text { Increased cellular density } \\
\text { of seminiferous Tubules }\end{array}$ & - & ++ & + & ++ \\
\hline Cellular death & - & ++ & + & ++ \\
\hline
\end{tabular}

+++ = Severe, $++=$ Moderate, + = Positive, $-=$ Négative/Normal/ Null .

localized edema and vaculations in the interstitial tissue of testis in the dandelion extract- (Photo 1) and synbiotic- (Photo 2) treated lambs. Less edema and vaculations were observed in probiotic-treated lamb testes (Photo 3). The dandelion extract-treated lambs also showed more histo-architecture disturbance of seminiferous tubules in testes (Photo 1) compared to probiotic- (Photo 3) and synbiotic- (Photo 4) treated lambs. These sections showed less increased cellular density and more cell death in the seminiferous tubules germinal cells of dandeliontreated compared to probiotic, synbiotic-treated and control lambs (Photo 4).

\section{DISCUSSION}

Dandelion is a biennial herbaceous plant native to temperate areas, and it contains large amounts of inulin $(12 \%-15 \%)$ and oligofructans in its tap roots [20,21]. Dandelion was found to have several medicinal benefits [22-24]. Dandelion compounds increase bile production and flow. The increased bile flow might improve cholesterol metabolism [24]. The leaves are used to help digestion, and as diuretic. Dandelion is promoted as a blood purifier. Dandelion root has been used to detoxify the liver and gallbladder, while its leaves used to support

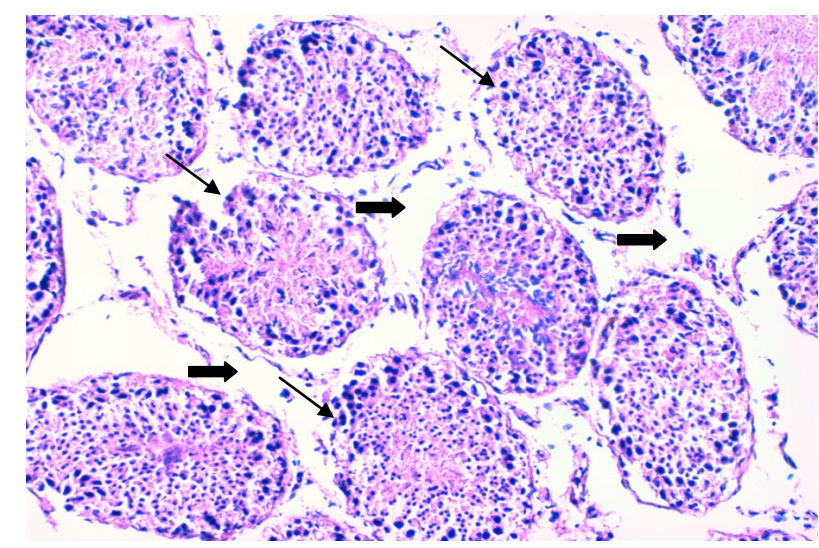

Photo 1. A cross section in a lamb testis given dandelion extract (prebiotic) showing testes histo-architecture disturbance seminiferous tubules (thin arrows), interstitial tissue edema and vaculation (thick arrows) $(\times 200)$.

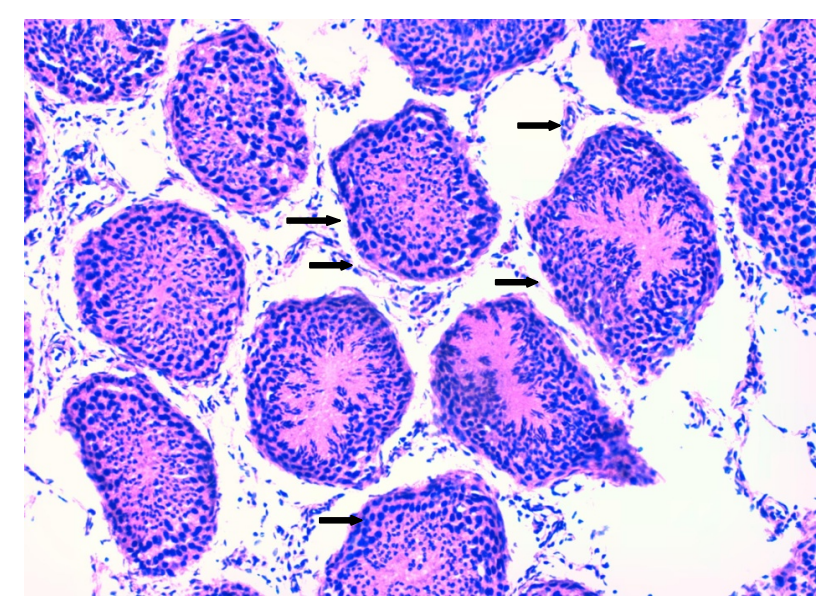

Photo 2. A cross section in a lamb (\#78) testis given synbiotic showing testes histo-architecture disturbance seminiferous tubules, interstitial tissue edema (thick arrows) $(\times 200)$.

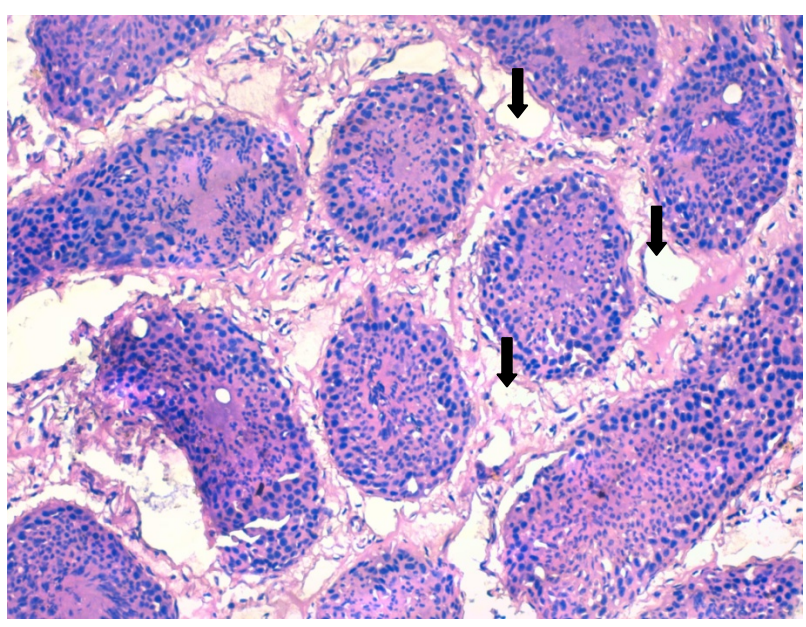

Photo 3. A cross section in a lamb (\#70) testis given cow milk probiotic showing interstitial tissue edema and vaculations (thick arrows) $(\times 200)$. 


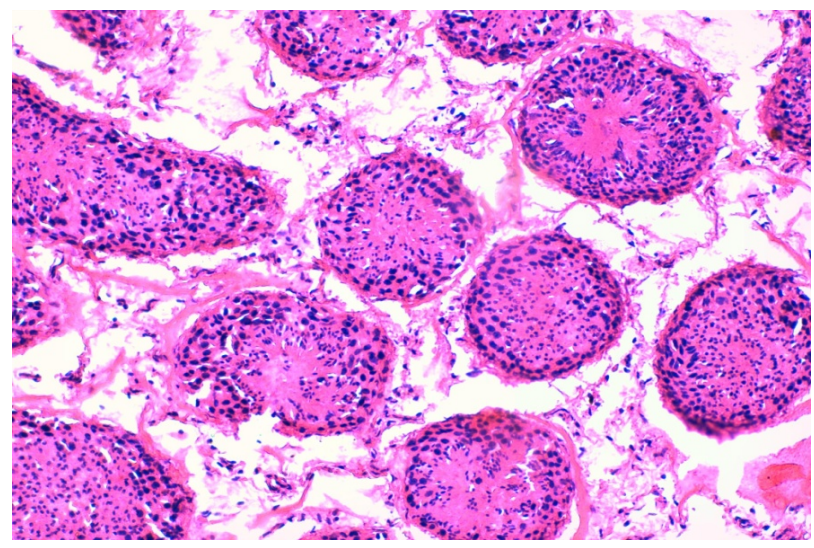

Photo 4. A cross section in a control lamb (\#48-control) testis showing normal histo-architecture seminiferous tubules, and interstitial tissue $(\times 200)$.

kidney function [25]. There have been well established reports of the significance of dandelion on hepatic cell function to synthesize the bile salts which are of relevance to human suffering liver cirrhosis. Above its effect on liver and bile secretion there exist a belief among public that dandelion enhances the aphrodisiac properties in males. Due to the lack of studies on the effect of dandelion on male reproductive performance in general and on farm animals male fertility in specific, this study was implemented to monitor these effects in ruminant animals since some pastures contain scattered plants of this weed. The testicular structure damage due to receiving dandelion aqueous extract might be due to its richness in alkaloids which might deteriorated the spermatogenesis within seminiferous tubules (Photo 1).

Leydig cells in the interstitium of testis are the primary source of testosterone, which stimulates the differentiation of the male phenotype and spermatogenesis in the testes [26,27]. Loss of Leydig cells significantly contributes to the age-related decline of serum testosterone [28-30]. Substantial losses in serum testosterone may result in the inactivation of spermatogenesis. In a recent study in rats [10] similar findings were obtained (i.e. reduced sperm count, low testosterone). They attributed these adverse effects of dandelion extract on sperm count and quality to the significant decrease of androgen receptors in seminiferous tubules. There found similar effects when Echinops echinatus roots (compositae) was given to male rats and these adverse effects on sperm and male hormone was attributed to the terpenoid content in the aqueous extract which exists in dandelion [31]. The decrease in sperm motility might be caused by a decrease in AT Pase activity which might be linked to defects in the ultrastructure of sperm [32].

However, in a study in mice there found a beneficial effect of dandelion extract administration by up regulating estrogen, progesterone and follicle stimulating hor- mone receptors in females [33]. Moreover, it is unknown the cause-result relationship of the significant decline in testosterone accompanied with the decline in sperm count and percentage of progressive motility. It is well known that androgens are essential for normal spermatogenesis and male fertility, but how androgens exert this effect remains uncertain. Androgen receptors (ARs) are expressed in several testicular cell types, but continuing uncertainty exists over which cell type mediates androgen control of spermatogenesis. Androgen signaling via Sertoli cells (SCs) is essential for complete spermatogenesis [34].

The present results were parallel to those in rats, who found that the testis cellular and histology structure is affected by toxicity of administration of the aqueous extract of dandelion (Taraxacum officinale) [10]. In the present study, cellular and tissue changes were noticed in the dandelion-treated lambs, including generalized and localized edema interstitial tissue. Edema is a clear sign of the toxic effect of aqueous extract of dandelion or increased permeability of interstitial blood vessels. The dandelion-treated animals also showed testes histo-architecture disturbance of seminiferous tubules which could proceed to edema. These dandelion animals also showed testicular cell death signs which might be due to apoptosis or arrest in spermatogenesis. In the lambs fed probiotic alone or in combination with dandelion, the histological picture was improved than in dandelion. The signs of improvements were decreases in the histo-architecture disturbance of seminiferous tubules and increased cellular density of seminiferous tubules. This useful effect could be due to antioxidative stress effects or the synergizing effects on the spermatogenesis due to probiotic components $[2-4,35]$. It has been found that probiotic bacteria exert an antioxidant effect on sperm to protect against the surrounding free radicals [36]. This would explain the less deteriorative effect of dandelion extract when mixed with probiotic (i.e. synbiotic) in our study. The adverse effect of dandelion and the ameliorative effect of probiotic on spermatogenesis and testosterone production wouldn't vary between rats (monogastrics) and rams (ruminants).

\section{CONCLUSION}

Ingesting dandelion (Taraxacum officinale) by males for curing constipation, hepatic and gall bladder malfunction or even for treating joints disorders must be cautioned not overconsumption to avoid the adverse effects on their fertility. Co-administration of probiotic fermented cow's milk alleviated the adverse effect of water extract of dandelion leaves on testes. Male animals grazing on a pasture containing this herb scattered within the forage crop must be hand removed. Also, a multidis- 
ciplinary study must be advanced on purifying the various constituents of dandelion as to test each single component on the testis functions.

\section{ACKNOWLEDGEMENTS}

The authors would like to acknowledge the technical support of Mr. Said Yusuf.

\section{REFERENCES}

[1] Blumenthal, M., Goldberg, A. and Brinckmann, J. (2000) Herbal medicine: Expanded commission E monographs. Integrative Medicine Communications, Newton, 78-83.

[2] Williams, C.A., Goldstone, F. and Greeham, J. (1996) Flavonoids, cinnamic acids and coumarins from the different tissues and medicinal preparations of Taraxacum officinale. Phytochemistry, 42, 121-127. http://dx.doi.org/10.1016/0031-9422(95)00865-9

[3] Peirce, A. (1999) The American Pharmaceutical Association practical guide to natural medicines. William Morrow and Company, Inc., New York.

[4] Ottariano, S.G. (1999) Medicinal herbal therapy: A pharmacist's view. Nicoln Fields Pub., Portsmouth.

[5] Weiss, R.F. (1988) Herbal medicine. AB Arcanum, Gothenburg.

[6] Duke, J.A. (1985) CRC handbook of medicinal herbs. CRC Press, Boca Raton.

[7] Blumenthal, M. (1998) The complete German Commission E monographs: Therapeutic guide to herbal medicines. 1st Edition, American Botanical Council, Austin, $684 \mathrm{p}$.

[8] Fleming, T. (1998) PDR for herbal medicines. Medical Economics Company, Inc., Montvale.

[9] Matsui, A.S., Rogers, J., Woo, Y.K., et al. (1967) Effects of some natural products on fertility in mice. International Journal of Experimental Medicine, 16, 414-424.

[10] Tahtamouni, L.H., Alqurna, N.M., Al-Hudhud, M.Y. and Al-Hajj, H.A. (2011) Dandelion (Taraxacum officinale) decreases male rat fertility in vivo. Journal of Ethnopharmacol, 26, 135, 102-109.

[11] AOAC (2000) Official Methods of Analysis. 17th Edition, Gaithersburg, Maryland.

[12] Moltz, L., Sörensen, R., Schwartz, U. and Hammerstein, J. (1984) Ovarian and adrenal vein steroids in healthy women with ovulatory cycles-selective catheterization finding. Journal of Steroid Biochemistry, 20, 901-905. http://dx.doi.org/10.1016/0022-4731(84)90403-5

[13] Tamime, A.Y. and Robinson, R.K. (1999) Yoghurt: Science and Technology. Woodhead Publishers, Cambridge.

[14] AOAC (1990) Official methods of analysis of the AOAC. 2, 1298 p.

[15] Meléndez, P. A. and Caprilesa, V. A. (2006) Antibacterial properties of tropical plants from Puerto Rico. Phytomedicine, 13, 272-276.

http://dx.doi.org/10.1016/j.phymed.2004.11.009
[16] SAS (2000) Statistical Analysis System User’s Guide. Version 8, SAS Institute, Cary NC.

[17] Steel R.G.D. and Torrie J.H. (1980) Principals of Statistics. McGraw-Hill Book Company Inc., NY.

[18] Humason, G.L. (1979) Animal Tissue Techniques. W.N. Freeman and Company, San Francisco. http://dx.doi.org/10.1016/j.jep.2011.02.027

[19] Petlevski, R., Hadzija, M., Slijepcević, M. and Juretić, D. (2008) Toxicological assessment of P-9801091 plant mixture extract after chronic administration in $\mathrm{CBA} / \mathrm{HZg}$ mice: A biochemical and histological study. Collegium Antropologicum, 32, 577-581.

[20] Schutz, K., Carle, R. and Schieber, A. (2006) Taraxacum: A review on its phytochemical and pharmacological profile. Journal of Ethnopharmacology, 107, 313-323. http://dx.doi.org/10.1016/j.jep.2006.07.021

[21] Shidoji, Y. and Ogawa, H. (2004) Natural occurrence of cancer-preventive geranylgeranoic acid in medicinal herbs. The Journal of Lipid Research, 45, 1092-1103. http://dx.doi.org/10.1194/jlr.M300502-JLR200

[22] Van Loo, J., Coussement, P., De Leenheer, L., Hoebregs, H. and Smits, G. (1995) The presence of inulin and oligofructose as natural ingredients in western diet. CRC Critical Reviews of Food Science and Nutrition, 35, 525-552. http://dx.doi.org/10.1080/10408399509527714

[23] Lans, C., Turner, N., Khan, T., Brauer, G. and Boepple, W. (2007) Ethnoveterinary medicines used for ruminants in British Columbia, Canada. Journal of Ethnobiology and Ethnomedicine, 3, 1-22.

http://dx.doi.org/10.1186/1746-4269-3-11

[24] Jeon, H.J., Kang, H.J., Jung, H., Kang, Y.S., Lim, C.M. and Kim, Y.M. (2008) Anti-inflammatory activity of Taraxacum officinale. Journal of Ethnopharmacology, 115 , 82-88. http://dx.doi.org/10.1016/j.jep.2007.09.006

[25] Mahesh, A., Jeyachandran, R., Cindrella, L., Thangadurai, D., Veerapur, V.P. and Muralidhara Rao, D. (2010) Hepatocurative potential of sesquiterpene lactones of Taraxacum officinale on carbon tetrachloride-induced liver toxicity in mice. Acta Biologica Hungarica, 61, 175-190. http://dx.doi.org/10.1556/ABiol.61.2010.2.6

[26] Zhang, Y., Ge, R. and Hardy, M.P. (2008) Androgenforming stem Leydig cells: Identification, function and therapeutic potential. Disease Markers, 24, 277-286. http://dx.doi.org/10.1155/2008/905025

[27] Chen, L., Zhao, Y. and Zhang, Y. (2012) Progress on the research of stem Leydig cell line in the testis of rodents. Wei Sheng Yan Jiu, 41, 158-162.

[28] Luo, L., Chen, H. and Zirkin, B.R. (1996) Are Leydig cell steroidogenic enzymes differentially regulated with aging? Journal of Andrology, 17, 509-515.

[29] Wu, C.Y., Yu, T.J. and Chen, M.J. (2000) Age related testosterone level changes and male andropause syndrome. Chang Gung Medical Journal, 23, 348-53.

[30] Wang, C., Hikim, A.S., Ferrini, M., Bonavera, J.J., Vernet, D., Leung, A., Lue, Y.H., Gonzalez-Cadavid, N.F. and Swerdloff, R.S. (2002) Male reproductive ageing: Using the brown Norway rat as a model for man. Novartis Foundation Symposium, 242, 82-97. 
http://dx.doi.org/10.1002/0470846542.ch6

[31] Padashetty, S.A. and Mishra, S.H. (2007) Effect of terpenoidal fraction of Echinops echinatus roots on reproductive parameters of male rats. Journal of Natural Medicines, 61, 452-457. http://dx.doi.org/10.1007/s11418-007-0173-4

[32] Thangaraj, K., Joshi, M.B., Reddy, A.G., Rasalkar, A.A. and Singh, L. (2003) Sperm mitochondrial mutations as a cause of low sperm motility. Journal of Andrology, 24, 388-392.

[33] Zhi, X., Honda, K., Ozaki, K., Misugi, T., Sumi, T. and Ishiko, O. (2007) Dandelion T-1 extract up-regulates reproductive hormone receptor expression in mice. International Journal of Molecular Medicine, 20, 287-292.

[34] Welsh, M., Saunders, P.T.K., Atanassova, N., Sharpe,
R.M. and Smith, L.B. (2009) Androgen action via testicular peritubular myoid cells is essential for male fertility. The FASEB Journal, 23, 4218-4230. http://dx.doi.org/10.1096/fj.09-138347

[35] Al-Sobayil, K.A., Zeitoun, M.M., Khalil, M.H. and Abdel-Salam, A.M. (2008) Effect of oral administration of a functional synbiotic syrup on libido, semen characteristics, serum testosterone and liver and kidney function of goat's bucks. Asian Journal of Biological Sciences, 1, 11-18. http://dx.doi.org/10.3923/ajbs.2008.11.18

[36] Yang, J.L., Wen, M., Pan, K.C., Shen, K.F., Yang, R. and Liu, Z.H. (2012) Protective effects of dietary co-administration of probiotic Lactobacillus casei on CP-induced reproduction dysfunction in adult male Kumming mice. Veterinary Research, 5, 110-119. 